\title{
GAMBARAN STATUS GIZI BALITA DI RT 03 / RW 09 KELURAHAN BAROMBONG KECAMATAN TAMALATE KOTA MAKASSAR
}

\author{
Yourisna Pasambo
}

\author{
Jurusan Keperawatan Politeknik Kesehatan Kementerian Kesehatan Manado
}

\begin{abstract}
ABSTRAK
Status gizi yang baik sangat diperlukan oleh manusia dalam semua rentang usia khusunya balita. Telah diketahui bahwa tumbuh kembang balita bergantung dari status gizi yang dimiliki oleh balita itu sendiri. Jumlah balita di RT 03 / RW 09 Kelurahan Barombong Kecamatan Tamalate Kota Makassar terus meningkat dari tahun ke tahun. Seiring dengan meningkatnya jumlah balita, orang tua juga harus dapat menjamin peningkatan status gizi balita tersebut. Penelitian ini bertujuan mengetahui status gizi balita yang ada di RT 03 / RW 09 Kelurahan Barombong Kecamatan Tamalate Kota Makassar. Jenis penelitian yang digunakan adalah penelitian deskriptif kuantitatif dengan metode pendekatan cross sectional. Variable yang diteliti adalah status gizi balita dengan mengukur tinggi badan (TB) dan berat badan (BB) balita. Alat bantu untuk mengambil data adalah meteran dan timbangan. Populasi penelitian adalah balita usia 1-5 tahun di RT 03 / RW 09 Kelurahan Barombong Kecamatan Tamalate Kota Makassar yaitu berjumlah 22 balita. Pemilihan sampel menggunakan total sampling, sehingga didapatkan jumlah sampel sebanyak 22 balita. Status gizi balita dinilai dengan menggunakan indeks BB/TB, dimana Status Gizi Baik jika indeks BB/TB > 90\%, Status Gizi Kurang jika indeks BB/TB $81 \%$ - 90\%, dan Status Gizi Buruk jika indeks BB/TB $<80 \%$. Hasil penelitian menunjukkan bahwa balita yang memiliki status gizi baik sebanyak 10 orang $(45,5 \%)$, yang memiliki status gizi kurang sebanyak 11 orang $(50,0 \%)$, sementara balita dengan status gizi buruk sebanyak 1 orang $(4,5 \%)$. Hasil ini menunjukkan bahwa balita dengan status gizi kurang lebih banyak daripada balita dengan status gizi baik. Salah satu hal yang menjadi penyebabnya adalah kurangnya intake nutrisi yang seimbang pada balita tersebut. Kondisi ini dapat didukung dengan kurangnya pengetahuan ibu tentang gizi seimbang. Kesimpulan dari penelitian ini adalah sebagian besar balita yang ada di RT 03 / RW 09 Kelurahan Barombong Kecamatan Tamalate Kota Makassar memiliki status gizi kurang. Disarankan kepada petugas kesehatan setempat agar dapat memberikan penyuluhan kesehatan kepada ibu-ibu balita tentang pentingnya status gizi yang baik bagi pertumbuhan fisik dan mental balita.
\end{abstract}

Kata Kunci : status gizi, balita

\section{PENDAHULUAN}

Status gizi merupakan keadaan tubuh sebagai akibat konsumsi makanan dan penggunaan zat-zat gizi. Status gizi ini menjadi penting karena jika tidak diperhatikan dengan baik maka dapat merupakan salah satu faktor risiko untuk terjadinya kesakitan dan kematian. Status gizi yang baik bagi seseorang akan berkontribusi terhadap kesehatannya dan juga terhadap kemampuan dalam proses pemulihan (Profil Dinkes Jateng, 2011).

Status gizi yang baik sangat diperlukan oleh manusia dalam semua rentang usia khusunya balita. Telah diketahui bahwa tumbuh kembang 
balita bergantung dari status gizi yang dimiliki oleh balita itu sendiri.

Balita adalah anak yang telah menginjak usia di atas 1 tahun atau yang lebih populer dengan pengertian usia anak di bawah lima tahun. Tumbuh kembang anak secara fisik terjadi pada masa balita. Pada usia tersebut, petumbuhan seorang anak sangatlah pesat sehingga memerlukan asupan zat gizi yang sesuai dengan kebutuhannya (Saraswati, 2010).

Pemantauan Status Gizi (PSG) yang dilakukan oleh Kementerian Kesehatan pada tahun 2015 menunjukkan hasil yang lebih baik dari tahun sebelumnya. Persentase balita dengan gizi buruk dan sangat pendek mengalami penurunan, dimana terdapat $3,8 \%$ balita mengalami gizi buruk. Angka ini turun dari tahun sebelumnya yakni 4,7\% (Doddy Izwardi,2015).

Adapun Status Gizi Balita menurut Indeks Berat Badan per Usia $(\mathrm{BB} / \mathrm{U})$ berdasarkan hasil PSG tahun 2015 yaitu gizi baik 79,7\%; gizi kurang 14,9\%; gizi buruk 3,8\%, dan gizi lebih 1,5\%. Sedangkan Status Gizi Balita menurut Indeks Tinggi Badan per Usia (TB/U), didapatkan hasil balita normal $71 \%$, sedangkan balita pendek dan sangat pendek sebanyak $29,9 \%$.

Dari data di atas dapat dilihat bahwa masih terdapat balita dengan status gizi kurang bahkan buruk. Hal ini tentunya berdampak buruk bagi pertumbuhan fisik, mental, maupun kecerdasan balita.

Dampak jangka pendek gizi buruk terhadap perkembangan balita menurut Nency dan Arifin (2010), diantaranya menjadikan anak apatis, gangguan bicara dan gangguan perkembangan yang lain. Sedangkan dampak jangka panjang adalah penurunan skor intelligence quotient (IQ), penurunan perkembangan kognitif, penurunan integrasi sensori, gangguan pemusatan perhatian, gangguan penurunan rasa percaya diri dan tentu saja merosotnya prestasi akademik di sekolah. Kurang gizi berpotensi menjadi penyebab kemiskinan melalui rendahnya kualitas sumber daya manusia dan produktivitas. Tidak heran jika gizi buruk yang tidak dikelola dengan baik, pada fase akutnya akan mengancam jiwa dan pada jangka panjang akan menjadi ancaman hilangnya sebuah generasi penerus bangsa.

Di RT 03 / RW 09 Kelurahan Barombong Kecamatan Tamalate Kota Makassar, diperoleh jumlah balita pada tahun 2010 sebanyak 6 balita $(7,78 \%)$, tahun 2011 sebanyak 13 balita $(10,01$ $\%$ ), tahun 2012 sebanyak 10 balita (13 $\%)$, tahun 2013 sebanyak 21 balita $(27,28 \%)$, dan tahun 2014 terdapat 27 balita $(35,07 \%)$.

Dari data di atas menunjukkan bahwa jumlah balita di RT 03 / RW 09 Kelurahan Barombong Kecamatan Tamalate Kota Makassar terus meningkat dari tahun ke tahun. Seiring dengan meningkatnya jumlah balita, orang tua juga harus dapat menjamin peningkatan status gizi balita tersebut.

Kejadian gizi kurang dan gizi buruk pada balita perlu dideteksi secara dini melalui intensifikasi pemantauan tumbuh kembang Balita di Posyandu, dilanjutkan dengan penentuan status gizi oleh bidan di 
desa atau petugas kesehatan lainnya. Penemuan kasus gizi buruk harus segera ditindaklanjuti dengan rencana tindak lanjut yang jelas, sehingga penanggulangan gizi buruk memberikan hasil yang optimal (Profil Kesehatan Jateng, 2011).

Menurut pengamatan peneliti pada balita di RT 03 / RW 09 Kelurahan Barombong Kecamatan Tamalate Kota Makassar menunjukkan bahwa balita cenderung memiliki nafsu makan yang kurang. Balita tersebut diberikan makanan yang sama setiap hari (tidak bervariasi) sehingga balita tersebut cenderung bosan dan malas untuk makan. Selain itu, balita tersebut juga dibiarkan oleh orang tua mereka untuk jajan snack setiap hari sehingga mereka merasa kenyang dan menjadi semakin malas untuk mengkonsumsi makanan yang sehat.

Peneliti juga mewawancarai beberapa ibu dari balita tersebut dan hasil wawancara menunjukkan bahwa ibu-ibu belum memahami tentang gizi seimbang dan belum memahami perlunya gizi yang baik untuk menunjang pertumbuhan balita mereka. Ibu-ibu hanya memberikan makanan seadanya kepada balita, bahkan mereka sering memberikan mie instan jika balita mereka malas makan nasi.

Berdasarkan latar belakang tersebut maka peneliti melaksanakan penelitian dengan Judul "Gambaran Status Gizi Balita di RT 03 / RW 09 Kelurahan Barombong Kecamatan Tamalate Kota Makassar Sulawesi Selatan".
Rumusan Masalah

Rumusan masalah dalam penelitian ini adalah "Bagaimana gambaran status gizi balita di RT 03 / RW 09 Kelurahan Barombong Kecamatan Tamalate Kota Makassar?"

Tujuan Penelitian

Penelitian ini bertujuan mengetahui status gizi balita yang ada di RT 03 / RW 09 Kelurahan Barombong Kecamatan Tamalate Kota Makassar.

TINJAUAN PUSTAKA

Desy Khairina

(2008)

menyatakan status gizi merupakan suatu ukuran tentang kondisi tubuh seseorang dengan membandingkan makanan yang dikonsumsi dan penggunaan zat-zat gizi di dalam tubuh.

Sementara menurut Sutomo dan Anggraini (2010), status gizi merupakan kondisi kesehatan tubuh yang diperoleh berkat asupan zat gizi dari makanan dan minuman yang dihubungkan dengan kebutuhan.

Penulis menyimpulkan bahwa status gizi adalah kondisi kesehatan tubuh yang bergantung dari jumlah asupan / intake nutrisi dan penggunaan nutrisi tersebut di dalam tubuh.

Pada kelompok usia balita, status gizi merupakan ukuran keberhasilan dalam pemenuhan nutrisi yang diindikasikan dengan berat badan dan tinggi badan anak (Beck dalam Creasoft,2008).

Menurut Santosa (2004), terdapat dua faktor mempengaruhi status gizi balita yaitu faktor internal dan faktor eksternal. Faktor internal adalah faktor 
yang ada dalam diri anak itu sendiri, yang terdiri atas status kesehatan, umur, jenis kelamin, dan ukuran tubuh. Status kesehatan berhubungan dengan adanya hambatan reaksi imunologis dan terjadinya prevalensi serta beratnya penyakit infeksi. Kejadian infeksi menyebabkan anak mengalami kehilangan nutrisi melalui muntahmuntah dan diare. Sementara faktor umur merupakan faktor yang sangat menentukan jumlah protein yang dibutuhkan balita dalam masa pertumbuhan.

Adapun faktor eksternal yang dapat mempengaruhi status gizi pada anak yaitu factor yang berasal dari luar anak tersebut. Faktor ini meliputi pendapatan orang tua, pendidikan dan pengetahuan orang tua serta kejadian infeksi (Radiansyah,2007).

Menurut Soetjiningsih (2002), masa balita merupakan masa penentuan tumbuh kembang seorang anak yang mana akan menjadi dasar terbentuknya manusia seutuhnya. Jika seorang anak mengalami kekurangan gizi, hal tersebut akan berdampak pada perkembangan mental maupun sosialnya, oleh karena itu keduanya harus mendapat perhatian baik dari pemerintah, masyarakat maupun orang tua. Salah satu indikator untuk menilai pertumbuhan fisik anak adalah dengan melihat status gizi anak dalam hal ini balita.

Menurut Dewi Hapsari (2014), terdapat beberapa cara yang bisa dilakukan untuk mengukur status gizi balita. Salah satunya adalah dengan mengukur berat badan dan tinggi badan balita. Berat badan balita diukur dengan cara menimbang berat badan balita pada timbangan yang sudah ada di Posyandu atau Puskesmas. Sedangkan tinggi badan diukur menggukanan meteran. Tinggi badan dapat menjadi indikator seorang balita kekurangan nutrisi, meskipun kadangkala balita memang terlahir orang tua yang memiliki tubuh pendek. Namun meskipun begitu tinggi badan juga dapat menjadi factor dan tanda balita terserang gizi buruk.

Berdasarkan berat badan (BB) dan tinggi badan (TB), maka status gizi dapat dinilai dengan menggunakan rumus :

$\frac{\mathrm{BB}}{\text { Indeks BB menurut TB }} \times 100 \%$

Hasil pengukuran tersebut diklasifikasikan menjadi :

a. Gizi Baik (Normal) : > 90\%

b. Gizi Kurang (Kurus) : 81\% $90 \%$

c. Gizi Buruk (Sangat Kurus) : $<80$ $\%$

\section{METODE PENELITIAN}

Penelitian ini dilaksanakan di RT 03 / RW 09 Kelurahan Barombong Kecamatan Tamalate Kota Makassar pada tanggal 07 s/d 26 September 2015.

Metode penelitian yang digunakan adalah penelitian deskriptif dengan mengukur BB dan TB balita di RT 03 / RW 09 Kelurahan Barombong Kecamatan Tamalate Kota Makassar. Populasi penelitian adalah balita usia 1-5 tahun di RT 03 / RW 09 Kelurahan Barombong Kecamatan Tamalate Kota 
Makassar yaitu berjumlah 22 balita. Pemilihan sampel menggunakan total sampling, sehingga didapatkan jumlah sampel sebanyak 22 balita.

Jenis penelitian yang digunakan adalah penelitian deskriptif kuantitatif dengan metode pendekatan cross sectional yaitu penelitian dengan melakukan pengukuran atau pengamatan variable pada saat yang bersamaan.

Variable yang diteliti adalah status gizi balita dengan mengukur tinggi badan (TB) dan berat badan (BB) balita. Alat bantu untuk mengambil data adalah meteran dan timbangan. Selanjutnya, status gizi balita dinilai dengan menggunakan indeks BB/TB, dimana Status Gizi Baik jika indeks BB/TB > 90\%, Status Gizi Kurang jika indeks BB/TB 81\% $90 \%$, dan Status Gizi Buruk jika indeks $\mathrm{BB} / \mathrm{TB}<80 \%$.

\section{HASIL DAN PEMBAHASAN}

Distribusi Responden Berdasarkan Umur

Tabel 1. Distribusi Responden Berdasarkan Umur

\begin{tabular}{|c|c|c|c|}
\hline $\mathrm{NO}$ & Umur & Jumlah & $\%$ \\
\hline 1 & $1-2$ tahun & 18 & 81,8 \\
\hline 2 & $3-5$ tahun & 4 & 18,2 \\
\hline & Total & 22 & 100 \\
\hline
\end{tabular}
diketahui bahwa responden yang berusia 1-2 tahun sebanyak 18 orang $(81,8 \%)$ sementara yang berusia $3-5$ tahun sebanyak 4 orang $(18,2 \%)$.

Distribusi Responden Berdasarkan Jenis Kelamin
Tabel 2.Distribusi Responden

Berdasarkan Jenis Kelamin

\begin{tabular}{|c|c|c|c|}
\hline NO & $\begin{array}{c}\text { Jenis } \\
\text { Kelamin }\end{array}$ & Jumlah & $\%$ \\
\hline 1 & Perempuan & 9 & 40,9 \\
\hline 2 & Laki-laki & 13 & 59,1 \\
\hline \multicolumn{2}{|c|}{ Total } & 22 & 100 \\
\hline
\end{tabular}

Berdasarkan tabel di atas, diketahui bahwa responden yang berjenis kelamin perempuan sebanyak 9 orang $(40,9 \%)$ sementara yang berjenis kelamin laki-laki sebanyak 13 orang $(59,1 \%)$.

Distribusi Responden Berdasarkan Status Gizi

Tabel 3. Distribusi Responden Berdasarkan Status Gizi

\begin{tabular}{|c|c|c|c|}
\hline NO & Status Gizi & Jumlah & $\%$ \\
\hline 1 & Baik & 10 & 45,5 \\
\hline 2 & Kurang & 11 & 50,0 \\
\hline 3 & Buruk & 1 & 4,5 \\
\hline \multicolumn{2}{|c|}{ Total } & 22 & 100 \\
\hline
\end{tabular}

Berdasarkan tabel di atas, diketahui bahwa balita yang memiliki status gizi baik sebanyak 10 orang $(45,5 \%)$, yang memiliki status gizi kurang sebanyak 11 orang $(50,0 \%)$, sementara balita dengan status gizi buruk sebanyak 1 orang $(4,5 \%)$.

Hasil penelitian ini menunjukkan bahwa balita dengan status gizi kurang lebih banyak daripada balita dengan status gizi baik. Status gizi kurang berhubungan dengan tidak terpenuhinya bahanbahan nutrisi seperti protein, 
karbohidrat, lemak, dan vitamin yang dibutuhkan oleh tubuh.

Salah satu hal yang menjadi penyebabnya adalah kurangnya intake nutrisi yang seimbang pada balita tersebut. Kondisi ini dapat didukung dengan kurangnya pengetahuan ibu tentang gizi seimbang. Ibu-ibu balita di RT 03 / RW 09 Kelurahan Barombong Kecamatan Tamalate Kota Makassar memiliki tingkat pendidikan yang rendah sehingga kemungkinan tidak memahami pentingnya gizi seimbang bagi pertumbuhan bayi dan balita. Menurut UNICEF (2013), salah satu hal yang berkontribusi dalam terjadinya masalah gizi kurang pada balita adalah pendidikan orang tua. Semakin tinggi pendidikan orang tua, maka kecenderungan status gizi anak juga semakin baik. Hal ini sejalan dengan hasil penelitian Handono (2012) yang menemukan bahwa pendidikan orang tua terutama ibu berpengaruh secara signifikan terhadap status gizi balita.

Penyebab lain yang mungkin adalah sebagian besar balita di RW 03 / RW 09 Kelurahan Barombong Kecamatan Tamalate Kota Makassar memiliki nafsu makan yang kurang (malas makan). Kemungkinan besar karena menu makanan yang tidak bervariasi sehingga anak mudah bosan. Hal ini dapat disebabkan oleh kurangnya pemahaman ibu dalam mempersiapkan menu makanan yang seimbang dan bervariasi. Menurut Wong et al (2014), masalah gizi kurang pada balita secara langsung disebabkan oleh anak tidak mendapatkan cukup asupan makanan yang mengandung gizi seimbang.
Menu yang bervariasi juga baik untuk meningkatkan status gizi karena tubuh memerlukan banyak kandungan zat untuk perkembangan dan pertumbuhan khususnya balita. Status gizi baik dipengaruhi oleh faktor nutrisi yang dikonsumsi oleh balita itu sendiri dimana nutrisi yang dikonsumsi memiliki kualitas dan kuantitas yang baik bagi pertumbuhan dan perkembangan balita.

Faktor lainnya yang menyebabkan status gizi kurang pada balita di RW 03 / RW 09 Kelurahan Barombong Kecamatan Tamalate Kota Makassar adalah seringnya balita mengalami infeksi seperti infeksi saluran pernapasan maupun infeksi pada saluran pencernaan. Hal ini sejalan dengan penelitian yang dilakukan oleh Astannudinsyah (2003) bahwa ada pengaruh penyakit TB Paru dan penyakit diare terhadap status gizi balita. Menurut Ingan Ukur Tarigan (2003), diare menyebabkan nafsu makan anak menurun sehingga jumlah makanan dan minuman yang masuk ke dalam tubuh berkurang dan menyebabkan gizi kurang pada anak tersebut. Pendapat yang sama juga disampaikan oleh Supariasa (2002) bahwa salah satu factor yang secara langsung berpengaruh terhadap status gizi balita adalah kejadian infeksi. Menurut Scrimshaw, et.al (1989 dalam Supariasa, 2002), terdapat hubungan yang erat antara infeksi (bakteri, virus dan parasit) dengan kejadian malnutrisi. Mekanismenya dapat berupa penurunan asupan zat gizi akibat kurangnya nafsu makan, menurunnya absorbsi makanan pada saat sakit, hilangnya cairan / zat gizi 
akibat penyakit diare, mual / muntah dan perdarahan terus menerus serta meningkatnya kebutuhan baik dari peningkatan kebutuhan akibat sakit dan parasit yang terdapat dalam tubuh

Dari 22 balita, terdapat 10 orang $(44,5 \%)$ balita dengan status gizi baik. Hal dapat dipengaruhi kemampuan dari orang tua khusunya ibu untuk memberikan nutrisi yang seimbang kepada balita. Menurut Almeitser (2002), factor yang dapat mempengaruhi status gizi yang baik pada balita antara lain pemberian makanan tambahan yang tepat, tingkat pendapatan keluarga yang tergolong tinggi, perilaku pemeliharaan kesehatan seperti mengkonsumsi makanan yang bergizi serta perilaku hidup bersih dan sehat (seperti mencuci tangan anak sesudah bermain, sesudah buang air, dan sebelum makan), serta pola asuh keluarga berupa pola pendidikan yang diberikan orang tua kepada anak-anaknya.

Status gizi yang baik pada sepuluh balita tersebut didukung dengan tercukupinya zat gizi sesuai kebutuhan mereka. Berbagai penelitian membuktikan bahwa zat gizi sangat diperlukan untuk mengatur berbagai fungsi tubuh, seperti fungsi kekebalan, pertumbuhan, dan kognitif. Jika tubuh mengalami kekurangan zat gizi, dapat menyebabkan anak mengalami gangguan belajar, penyakit, bahkan kematian. Menurut Hardywinoto (2002), kecukupan zat gizi merupakan prasyarat yang sangat penting dalam pertumbuhan dan perkembangan anak, termasuk didalamnya perkembangan otak.

\begin{abstract}
Kekurangan beberapa zat gizi akan berdampak negative pada perkembangan otak. Karena masih dalam tahap pertumbuhan dan perkembangan, anak membutuhkan energy dan protein per kilogram berat badan yang lebih banyak dari orang dewasa. Sehingga kelengkapan zat gizi dalam makanan merupakan hal yang mutlak dan sesuai dengan angka kecukupan gizi. (Zaviera,2008).
\end{abstract}

\section{KESIMPULAN DAN SARAN}

Kesimpulan

Kesimpulan dari penelitian ini adalah sebagian besar balita yang ada di RT 03 / RW 09 Kelurahan Barombong Kecamatan Tamalate Kota Makassar memiliki status gizi kurang.

Saran

Disarankan kepada petugas kesehatan setempat agar dapat memberikan penyuluhan kesehatan kepada ibu-ibu balita tentang pentingnya status gizi yang baik bagi pertumbuhan fisik dan mental balita serta dampak yang dapat ditimbulkan jika balita mengalami kekurangan gizi.

\section{DAFTAR PUSTAKA}

Bantamen, Belaynew, \& Dube (2014). Assessment of Factors Associated with Malnutrition among Under Five Years Age Children at Machakel Woreda, Northwest Ethiopia: A Case Control Study. Journal nutrition food science vol 4 No 12014 
Handono, N.P (2012). Hubungan Tingkat Pengetahuan pada Nutrisi, Pola Makan, dan Tingkat Konsumsi Energi dengan Status Gizi Anak Usia Lima Tahun di Wilayah Kerja Puskesmas Selogiri, Wonogiri. Jurnal Keperawatan Vol 1 No.1, Juli 2010.

Ingan Ukur Tarigan. Faktor-faktor yang Berhubungan dengan Status Gizi Anak Umur 6-36 Bulan Sebelum dan Saat Krisis Ekonomi di Jawa Tengah. Buletin Penelitian Kesehatan Volume 31 No 1.2003

United Nations Children's Fund (UNICEF) (2013).Improving child nutrition: the achievable imperative for global progress, UNICEF, New York, 2013.

Wong et al.(2014). Risk factors of malnutrition among preschool children in Terengganu, Malaysia: a case control study. BMC Public Health Journal 2014, 14: 785

Saraswati, 2010. Hubungan Antara Status Gizi Dengan Perkembangan Balita. (online) http://www.acadenia.edu diakses 26 Mei 2015

Profil Dinkes Jateng, 2011. Cakupan Balita Gizi Buruk Mendapat Perawatan. (online), www.depkes.go.id diakses 26 Mei 2015
Nency dan Arifin, 2010. Gizi Buruk Ancaman Generasi Yang Hilang. (online) www.indonesiapublichealth.com diakses 26 Mei 2015

Khairina,Desy. 2008. Faktor-faktor yang Berhubungan dengan Status Gizi Pembantu Rumah Tangga berdasarkan IMT di Perumahan Duta Indah Bekasi. FKM UI. Jakarta

Dewi Hapsari, 2014. Waspadai Gizi Buruk Pada Balita. Tugu Publisher 